Potravinarstvo Slovak Journal of Food Sciences

vol. 15, 2021, p. 131-142

https://doi.org/10.5219/1485

Received: 19 October 2020. Accepted: 17 February 2021.

Available online: 28 February 2021 at www.potravinarstvo.com

(C) 2021 Potravinarstvo Slovak Journal of Food Sciences, License: CC BY 4.0

ISSN 1337-0960 (online)

\title{
CONSUMER PREFERENCES ON THE MARKET OF PLANT-BASED MILK ANALOGUES
}

\author{
Natalia Pritulska, Iuliia Motuzka, Anna Koshelnyk, Olena Motuzka, Ludmila Yashchenko, \\ Malgorzata Jarossová, Paulína Krnáčová, Joanna Wyka, Ewa Malczyk, Marta Habánová
}

\begin{abstract}
The consumption of plant-based food products instead of animal-based products tends to increase worldwide which can be caused by the global expansion of alternative food products. The article's objective is to investigate the perception of plant-based milk analogues by real and potential consumers and determine the prospects of increasing their assortment. The assortment of plant-based analogues of milk and products made thereof is analyzed. A projection of the almond milk sales was made as one of the most effective product categories. Questioning of consumers conducted to investigate consumer treatment of plant-based milk analogues. The survey covered 436 respondents, of which $37.7 \%$ consume plant-based milk regularly and $47.7 \%$ of respondents consume this product occasionally. About $15 \%$ of respondents have never consumed it. The results show that experimenting with diets and health concerns more often young people (under 30 years of old). Plantbased milk was consumed by men (47.6\%) and women (52.4\%). Prices for plant-based milk analogues are too high, and its reduction will increase the sales of this product according to respondents. The taste is one of the crucial factors in choosing plant-based milk analogues by respondents. By taste-based preference, the largest shares are with almond milk (20.4\%) and oat milk (15.3\%). At the same time, $16.2 \%$ of the respondents have no preference regarding plant-based milk analogues. It was found that using the titles of traditional milk products for naming plant-based milk analogues is not troublesome for most of the respondents. The derived figures give evidence that consumers, not being sufficiently aware of the origin of plant-based milk analogues, do not understand the differences between traditional products and their plant-based analogues.
\end{abstract}

Keywords: consumer properties; plant-based milk analogues; fenugreek; consumer preferences; market

\section{INTRODUCTION}

Balanced nutrition is an integral part of a healthy way of life. Currently, there is a worldwide trend that the consumption of plant-based food products substitutes the consumption of animal-based products. According to some nutritionists, the reason is that such food products can be better digested and do not contain harmful hormones and antibiotics that may be found in animal-based food products (Bestfoodfacts, 2017). Haas et al. (2019) claim that plant milk consumers evaluated plant milk significantly better; they considered plant milk much better digestible and allergy-free.

Furthermore, the share of consumers with intolerance of lactose and milk allergy, which replace the products with lactose or milk proteins from the diet and replace them with plant proteins, has recently grown. From this point of view, the assortment of food products has been widening in the world by including food products oriented on special population groups, alternative food products in particular: plant-based analogues of milk and dairy products, meat, etc. Another reason for the rapidly growing popularity of plant-based alternatives is that their manufacturing is more environmentally friendly than the manufacturing of animal-based food products.

The usefulness of such products results from the absence of lactose, milk proteins, cholesterol, and lower caloricity compared to traditional milk. Since utility characteristics of plant-based analogues of milk also depend on the raw material from which they are made, they are used as the basis to produce food products for medical purposes (Stannard, 2018; Vanga and Raghavan, 2018; Sethi, Tyagi and Anurag, 2016). For example, soymilk isoflavones contribute to the prevention of osteoporosis, atherosclerosis, cancer, and cardiovascular diseases, inhibit the aging process, etc. (Omoni and Aluko, 2005). Phytosterols of rice milk exhibit anti-diabetic, antiinflammatory, and antioxidant properties; contribute to lowering cholesterol and high blood pressure (Biswas et al., 2011). Milk from almond contains arabinose and alpha-tocopherol, making it antioxidant and prebiotic (Burton and Ingold, 1989; Mandalari et al., 2008).

The rapid growth of the number of people with diets including only plant-based food products is reported in EU countries as follow: 8 million in Germany, 800 thousand in Belgium, 3.3 million in France, 200 thousand in Greece, 
800 thousand in the Netherlands, etc. (The Vegan Society, 2018). The ever-growing consumption of mostly plant-based food products are observed in Eastern European countries. Thus, according to expert data, 2 million people in Ukraine abandon meat and stick to diet systems like vegetarianism, veganism, with raw food diets gaining in popularity (Zik, 2017). However, consumers often complain that plant-based food product offer is limited in the market. That also refers to specific categories of population (people with certain illnesses, allergies, etc.), for which accessible food products are mostly produced abroad. There is a need to supply the market with food products made of raw materials of domestic origin. Therefore, research of the trends in the global market of plant-based analogues of milk products is important. The research focused on the market tendencies and outlooks in the field of plant-based alternatives is episodic and systematic analytical information is currently missing. An important aspect of research represents the analysis and systematization of data on the current assortment of this product category and its relevance to consumer needs and expectations.

Investigation of the consumer behavior focused on their motivation and perception of a given product has great significance in forming the assortment of plant-based milk analogues.

As plant-based analogues of milk and other plant-based food products are rather new product groups on the consumer market, analyses of their assortment and dynamics of their market have been out of research focus. Research devoted to the performance of the food industry in the overall or market tendencies in traditional milk products is shown in works of many scientists, such as Burke et al. (2018); Haghighat, Thimmarayappa and Niavand (2015); Popescu (2015); Tycha and Stetsenko (2017); Karpii, Khtei and Shul (2013); Havaza (2015); Ilchuk and Radko (2013); Fedulova (2018); Vlasenko (2013) and others. These research works are confined to market analysis and areas of assortment expansion for certain categories of milk and dairy products consumers, with plant-based analogues left out of focus.

Regarding the market of plant-based analogues of food products and particularly milk and dairy products analogues, researchers such as Lagally, Clayton and Specht (2017); Wild et al. (2014); Doris (2018) investigated issues of market dynamics and technological specifics of product manufacturing. There is a lack of summed up and systematized approaches to the analysis of the current performance of the market of plant-based analogues of milk products. Issues related to factors determining the assortment of this product group and considering consumer needs, potentials for expansion of the resource base for their manufacturing remain unsolved.

It should be noted that the term "plant-based milk" is not correct, as this drink takes origin from the extract of seeds, nuts, or cereals mixed with water in a certain proportion. The most widespread notions today are "plant-based substitute of milk", "alternative milk" (according to literature sources), and, accordingly, "alternative milk products", as well as "plant-based analogue of milk". In our opinion, the correct term for the name of the studied products is plant-based milk analogues. Using other terms can mislead consumers because their meaning implies the identity of the nutritional and biological value of traditional milk and its plant-based analogues (Koshelnyk, Motuzka and Babiy, 2020).

\section{Scientific hypothesis}

The article's objective is to investigate existing and potential consumers' preferences for plant-based milk analogues and to determine the prospects for increasing their assortment.

According to the objective, the scientific hypotheses were set:

Hypothesis 1: There is a difference between consumer perceptions of the nutritional value of plant-based milk and traditional milk.

Hypothesis 2: The demand for plant-based milk analogues may be increased throughout attracting potential consumers.

Hypothesis 3: The assortment of plant-based analogues of milk and dairy products should be increased by launching new products into the market.

Hypothesis 4: The majority of consumers consider prices of plant-based milk analogues to be too high.

\section{MATERIAL AND METHODOLOGY}

This research was conducted by the use and processing of primary and secondary data. The information base of the research is official statistical reports of the State Statistics Service of Ukraine, data from international organizations (FAO, UN, etc.), scientific literature (data of domestic and foreign scientists), and Internet resources. This research is conducted using the methods of statistical and system analysis, generalization, comparison, etc. The primary data was obtained by the questioning of consumers, intended to determine key factors behind the consumption of plant-based milk analogues in Ukraine. The questioning was conducted in 2019 - 2020 online, using the Google Forms platform. The questioning covered 436 respondents, of which $37.7 \%$ consume plant-based milk on regular basis, $47.7 \%$ consume it occasionally, and a $14.9 \%$ never consume it. According to the age structure of those who consume plant-based milk analogues, the largest group consists of respondents aged 25 to 30 years $(43.2 \%)$, then - aged 18 to 24 years (28.4\%), the smallest group consists of respondents older than 50 years. The results show that young audiences respondents (under the age of 30) are more inclined to experiment with nutrition and they take care of their health (namely the consumption of non-traditional milk). In general, both men (47.6\%) and women $(52.4 \%)$ consume plant-based milk analogues approximately equally.

\section{Statistical analysis}

A comparison of plant-based milk analogues between those who consume them and those who do not consume them was based on a statistical assessment of similarities between the shares of responses.

Large scopes of experimental data demonstrate that the test to check the significance of the paired correlation coefficients is applicable for assessing the similarities in the structure of variables. For the experiment presented in the article, the hypothesis $H_{0}$ implies that there are no significant variations between those who consume 
plant-based milk and those who do not consume it, i. e. the structures of responses are similar. In this case, $p<0.05$, which confirms the significance of the criterion. In the other case $(p>0.05)$, there are large variations between the shares of responses.

The criterion was computed by the software for statistical analysis of data IBM SPSS Statistics V.21 in the subsection "T-criterion" for the paired samples of the section "Comparison of averages". To make parametric criteria applicable, the data were checked for the normality of distribution by the Kolmogorov-Smirnov criterion in the section "Non-parametric criteria". This criterion enables us to confirm the normality of the data because all the computed $p$-values $>0.05$. This demonstrates that the values of the variables follow the normal distribution well enough so that the parametric tests can be applied.

The regression analysis, used for projecting the sales of almond milk, is realized in MS Excel 2016 software package using the application? "Data analysis", "Regression" module. The computation algorithm for the annual projected values of the indicator was the use of linear regression (Yashchenko, 2016). The computation algorithm for projected values of sales in almond milk using linear regression includes the following four phases:

1) Setting of the parameters and computation of the trend, 2) Assessment of the trend quality, 3) Determining the trend coefficients, 4) Deriving the estimates and the projection using the trend coefficients and the values of the time parameter. A detailed description of the project phases is given below.

Phase 1. Annual projected values of the indicator are computed by the equation:

$$
\widehat{Y}=a_{0}+a_{1} \cdot t
$$

where $\hat{Y}$ - annual estimates of the indicator;

$a_{0}$ and $a_{1}$ - equation coefficients;

$t$ - time parameter $(t=1, \ldots, n, n$ - number of years $)$.

The equation (1) is built based on linear regression, which involves the construction of a straight line with the values of indicators located on it maximally approximated to the actual ones.

Phase 2. The equation assessment is made by the coefficient of determination and the significance test criteria:

\section{The coefficient of determination.}

The share of dispersion that is explained by the linear relationship in the overall dispersion of the effective feature $Y$ is characterized by the coefficient of determination.

The nearer is the value of the coefficient of determination to 1 , the more accurate is the choice of the equation. When its value is higher than 0.8 , the equation will be considered accurate, and when it is lower than 0.5 , the equation will require refinement either through selecting other factors or by increasing the period for the available data.

2. The equation significance test: the hypothesis on the existence of the linear relationship between independent and dependent variables is checked by Fisher's ratio test.
Two hypotheses are checked for this purpose: $\mathrm{H}_{\mathrm{o}}$, which does not imply a relationship between the values $\mathrm{t}$ and $\mathrm{Y}$, and $\mathrm{H}_{1}$, which implies a relationship between the variables. When the value of $p$ is higher than 0.05 , then the hypothesis $\mathrm{H}_{\mathrm{o}}$ will be accepted, with the equation referred to as insignificant or inadequate. And when the value of $p$ is lower than 0.05 , then the hypothesis $\mathrm{H}_{1}$ will be accepted, with the equation referred to as significant or adequate, i. e. applicable for further computations.

3. The significance of equation coefficients is assessed by Student's t-test.

Two hypotheses are also checked for this purpose: $\mathrm{H}_{0}$, which implies that the variable $t$ does not have a heavy influence on the variable $\mathrm{Y}$, and $\mathrm{H}_{1}$, which implies that the influence is heavy. When the value of $p$ is higher than 0.05 , then the hypothesis $\mathrm{H}_{\mathrm{o}}$ will be accepted, with the coefficient at the variable $t$ referred to as insignificant. And when the value of $p$ is lower than 0.05 , then the hypothesis $\mathrm{H}_{1}$ will be accepted, with the coefficient at the variable $\mathrm{t}$ referred to as significant, meaning that it can be relied upon in making conclusions about the relationship between the variables.

In our case, the derived coefficient of determination and the test significance criteria confirm the applicability of the equation for further projections.

Phase 3. The equation coefficients are computed by the method of least squares. This method minimizes the sum of the squares of deviations of actual values from estimated ones:

$\sum\left(Y_{i j}-\hat{Y}_{i j}\right)^{2} \rightarrow \min$

It allows us to derive $a_{0}$ and $a_{1}$ - the coefficients of the equation (1).

Phase 4. To compute the annual projected values of the indicator, we have to insert the derived coefficients and the time parameter value in equation (1):

$$
(p=0002, \text { i. e. } p<0.05)
$$

\section{RESULTS AND DISCUSSION}

The global market of plant-based food products has been undergoing rapid development. The year 2016 was declared the Year of the Pulse by the United Nations Organization due to the rapidly growing demand for plant proteins and beans, lentils, peas, chick-peas, etc. in particular (FAO, 2016). The research company Mintel refers to this global trend in nutrition as "power of plants". According to the outlooks of American analytical companies, the share of plant-based food products will exceed the animal-based ones by $20 \%$ in 25 years. The report of Nielsen Holdings PLC from September 2018 shows that compared with 2017 the market of plant-based food products grew by $20 \%$ and exceeded 3.3 billion USD (Zegler, 2017). 


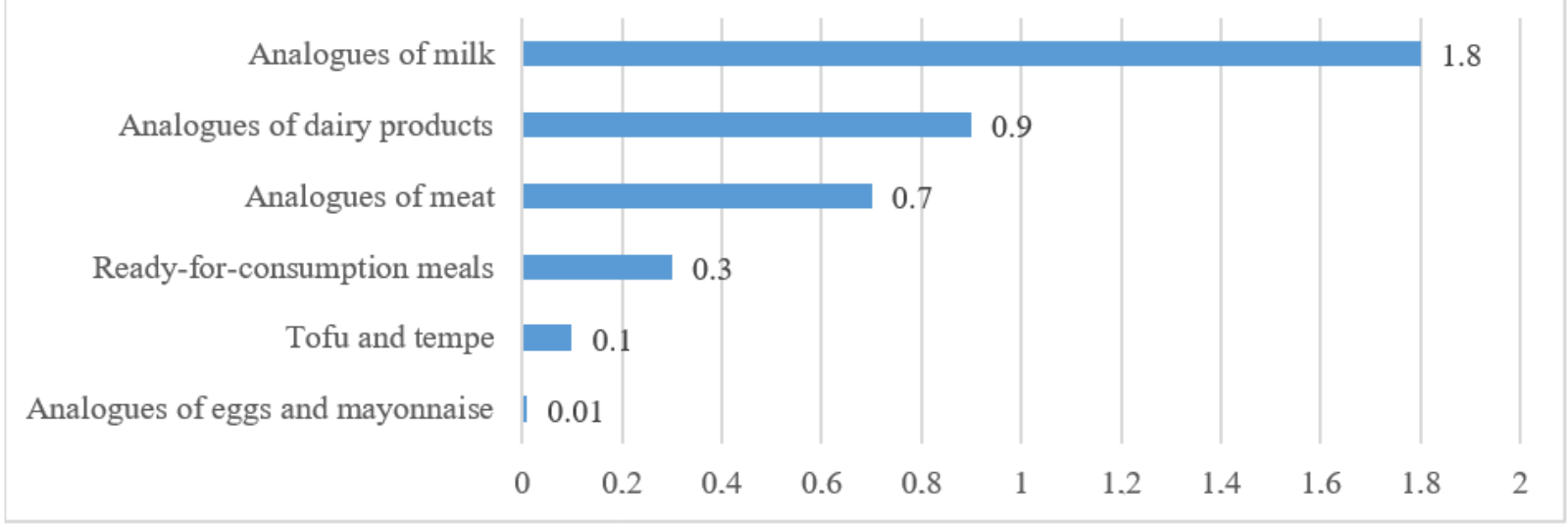

Figure 1 The retail market of plant-based analogues of food products in billion USD.

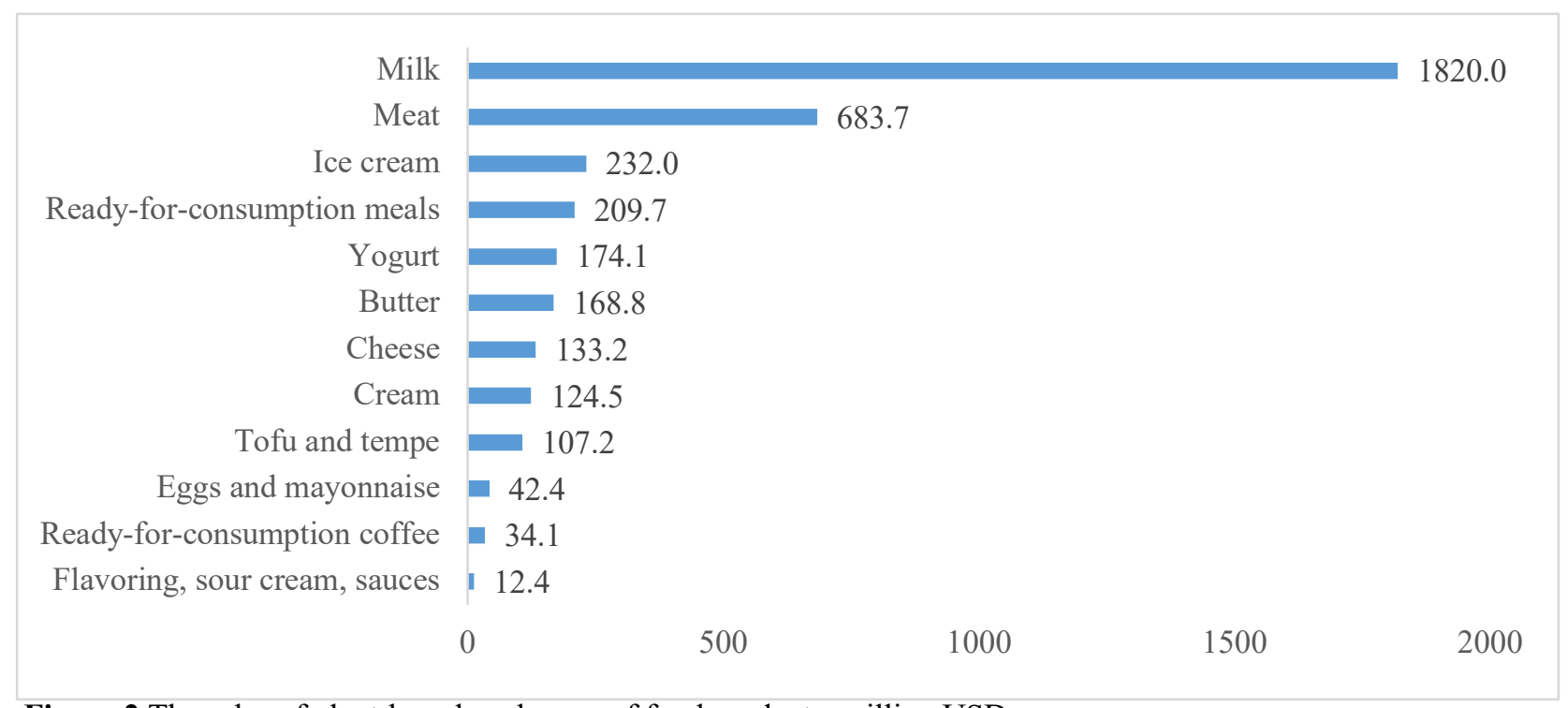

Figure 2 The sales of plant-based analogues of food products, million USD.

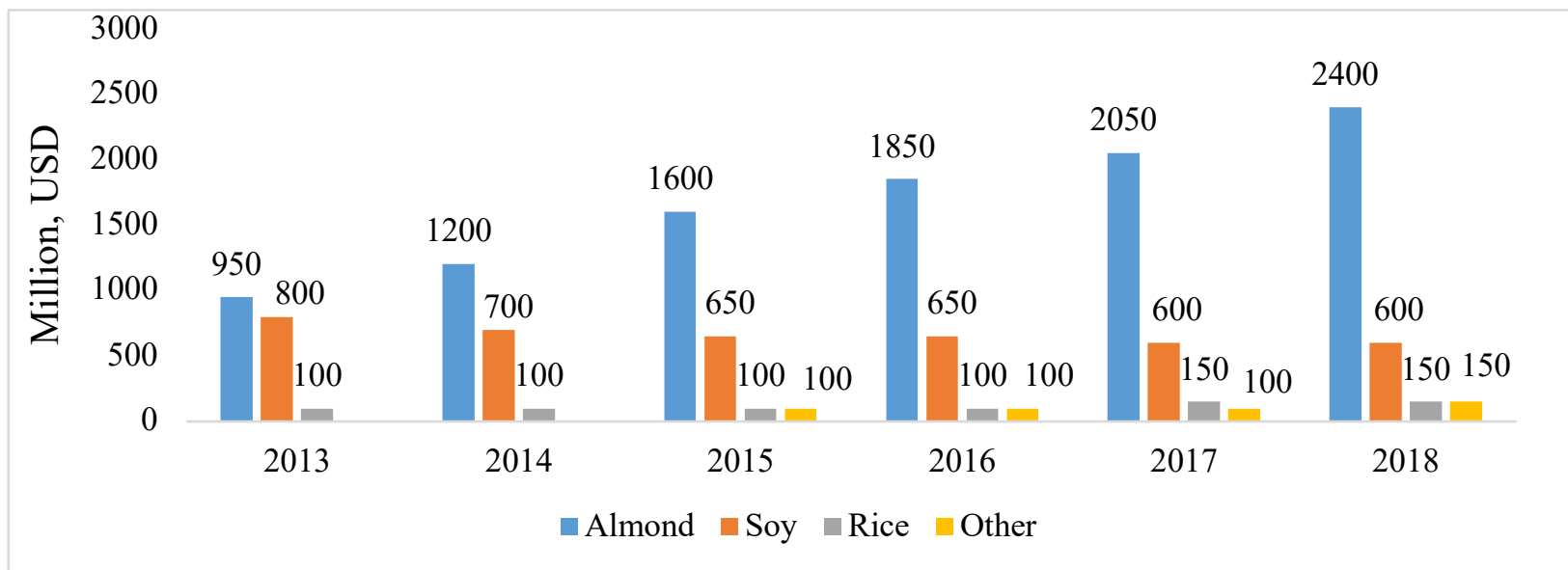

Figure 3 Sales of plant-based milk analogues by category, million USD. 
The assortment of plant-based food products is quite extensive and represented by confectionery and baked products, sauces, plant-based substitutes of meat and meat products. In November 2018, the total sales of food analogues reached 3700 million USD (Crosser et al., 2019). Kubicová and Habánová (2012) claim that the consumption of milk (excluding cheese, cottage cheese, sour milk products, and butter) decreased in the past 17 years. For example, milk demand and its consumption in Slovakia decreased annually by up to $1.88 \mathrm{~kg}$ per capita that is largely caused by an increase in milk prices and an increase in the range of high-quality plant-based milk analogues and their pleasant organoleptic characteristics. Krivošíková et al. (2019) also claim that milk consumption in the Slovak Republic is insufficient. The retail market of plant-based analogues of food products is shown in Figure 1.

The largest market share belongs to plant-based analogues of milk. Their sales on the alternative food market are worth 1.8 billion USD. The second rank holds analogues of dairy products: yogurts, creams, ice creams, etc. (0.9 billion USD). Plant-based analogues of meat also have a considerable share ( 0.7 billion USD). Other food products are being launched to the market, and their share is relatively small ( 0.3 billion USD for ready-toconsumption meals; 0.1 billion USD - tofu and tempeh; 0.01 billion USD - analogues of eggs and mayonnaise) (Future Market Insights, 2019).

The sales of plant-based analogues of food products are shown in Figure 2.

It shows that the largest sales reached plant-based analogues of milk (1820 million USD), followed by analogues of meat (683.7 million USD). Other popular milk analogues are ice cream, yogurts, butter, cheese, cream, etc. It should be noted that a special commodity category constitutes ready-to-consumption meals made of plant ingredients and imitating traditional meals cooked by the use of animal-based components by appearance and taste.

Companies leading the global market of plant-based analogues of milk are «The Hain Celestial Group», «Koninklijke Wessanen», «Organic Valley Cropp Cooperative», «SunOpta», «OATLY», «Califia Farms», «Eden Foods», «Danone», «Earth's Own Food Company», «Blue Diamond Growers» and others.

There are many kinds of vegetable raw materials, which are used to produce drinks. Since it is a relatively new product category, a classification of plant-based analogues of milk is missing in the literature. However, an attempt of the overall classification of these products is made in some scientific works, with outlining five categories of drinks made of raw materials as follow (Sethi, Tyagi and Anurag, 2016; Vanga and Raghavan, 2018):

-cereals: oat, rice and/or corn milk, and milk made of spelt; -soybeans: soy milk, milk made of peanut, lupine, Chinese black-eyed peas;

-nuts: almond, cocoa, and/or pistachio milk, milk made of hazelnut and walnut; -seeds: sesame milk, milk made of sunflower, flax, cannabis, and other seeds;

-pseudo-cereals: milk made of quinoa, amaranth.

The most widespread plant analogues of milk are made of soybeans, almonds, rice, and cocoa; drinks made of quinoa, sesame, and spelt can also be found.

Manufacturers can expand the assortment of drinks by adding cocoa, vanilla fruit fillers, etc.

The largest consumption of plant-based drinks is recorded in the U.S. and Canada. While sales of alternative milk grew by $61 \%$ in $2012-2017$, sales of cow milk fell by $15 \%$. Company Future Market Insights (2019) expects that the market of plant-based substitutes of animal milk will grow up to reach 9.5 billion USD by the end of 2022 , with an annual increase of $7.1 \%$. As estimated by «Euromonitor», since the beginning of 2014 sales of alternative milk drinks grew by $31 \%$ in the U.S., by $24 \%$ in Europe, by $14 \%$ in the Asian-Pacific area, by $17 \%$ in Latin America. According to «Innova Market Insights», the global market of "plant-based milk" exceeded 16 billion USD in 2018 (Innova Market Insights, 2017). According to data in Figure 3, the sales of soymilk are lower in 2018 compared to the previous years (Proconsulting, 2019; Agroreview, 2018). As rice milk is popular mostly in Asia, its sales are considerably lower than the other categories of milk. The sales of other categories of milk are quite the same, but data from 2013 and 2014 are missing. This may be caused by the fact that many kinds of alternative drinks were launched on the market in recent years. The largest demand is reported for almond milk and we expect that its sales will grow.

Data in Figure 3 in the text demonstrate that the sales of almond drinks are the most effective of all the plant-based milk analogues. The regression equation (Figure 4) enables us to reveal that from 2013 to 2018 the average annual growth in sales of almond milk made 287.14 million USD. According to our projections, sales can reach 3254 million USD in 2021. Considering the popularity of a vegetarian diet and the intensifying movement for animal wellbeing, these figures are expected to be increasing. This is confirmed by cases of milk farms in the U.S., which exchange animal breeding for plant growing, and European farms that switch from the traditional production of milk to plant growing only. The most significant reasons encouraging people to stick to plant-based diets are as follows: care about animals, improvement of health, the negative impact of meat and dairy production on the environment; safety of these food products, price, distrust to the labeling of animal-based food products, etc. (Stannard, 2018). The strongest motivating factor for people to consume plant-based food products is the ethical treatment of animals, striving to improve health, and belief that the manufacturing of meat and dairy products has negative environmental effects. Furthermore, there are several media reports on the high consumption of natural resources for the production of animal-based food products and its contribution to the greenhouse effect, entailing global warming. 


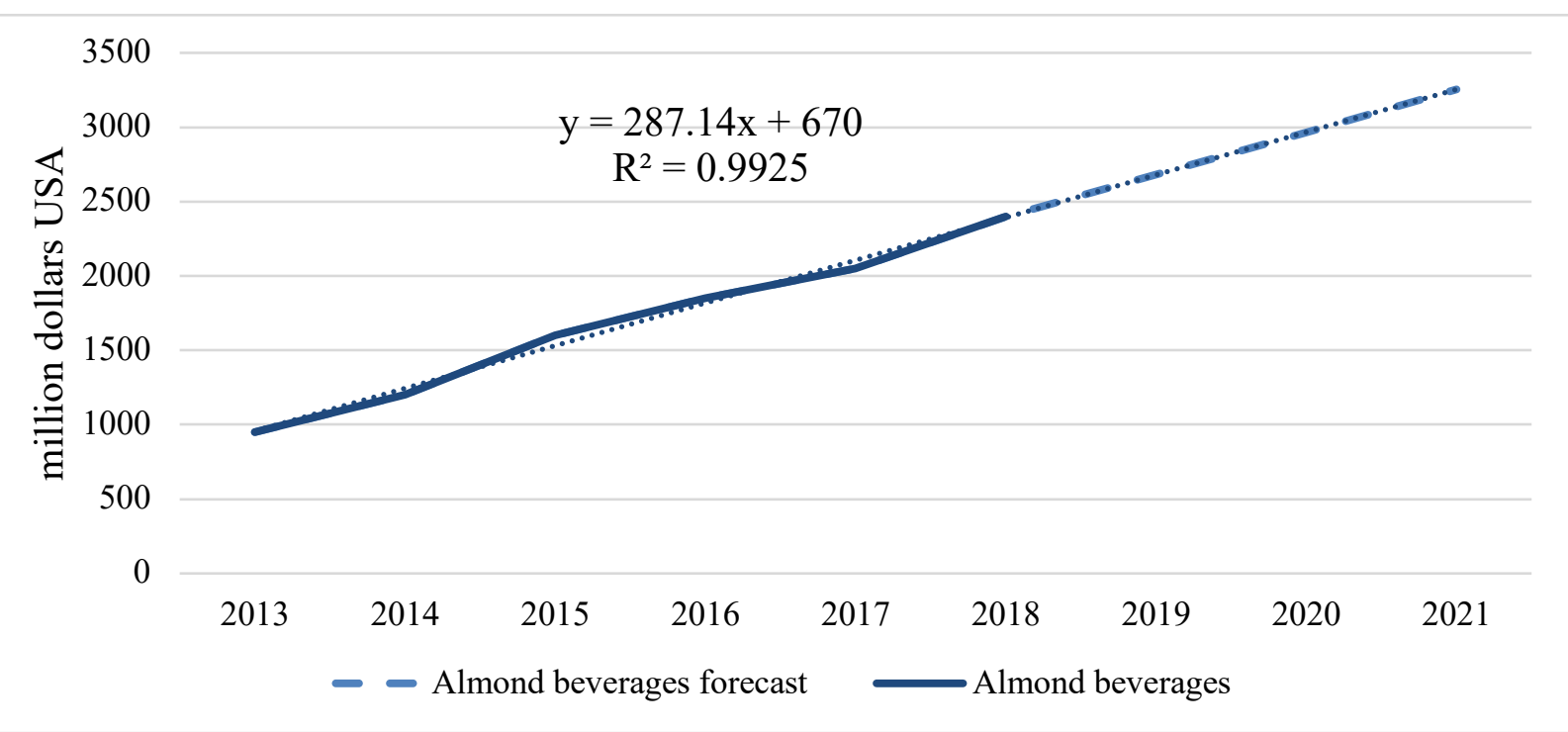

Figure 4 The reported and projected sales dynamics for almond beverage.

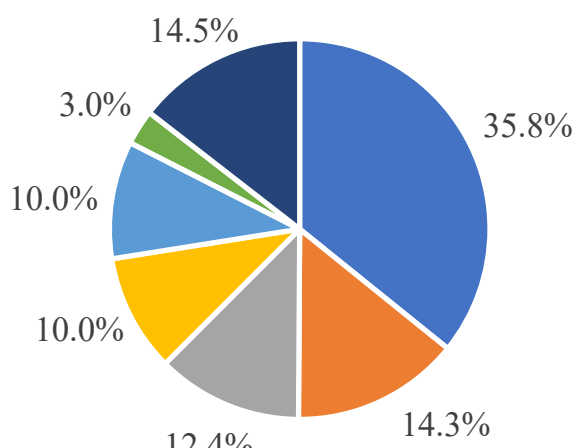

- Commitment to the healthy life style - Health condition (lactose intolerance)

- Enjoyment of the product taste $\quad$ Ethical treatment of animals

- Environmental concerns - Milk allergy

- Other

Figure 5 The reasons driving the respondents to consume plant-based milk analogues.

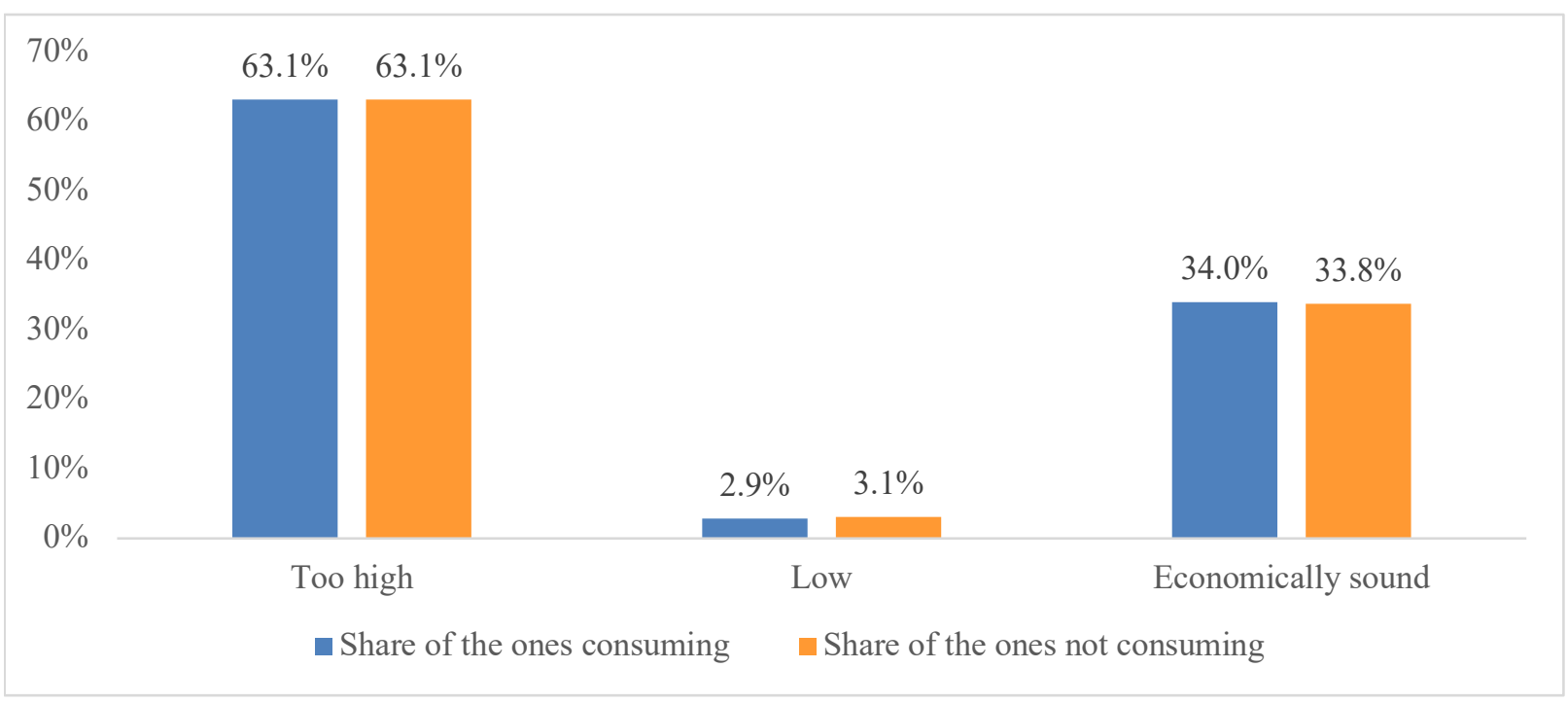

Figure 6 The assessment of price for plant-based milk analogues. 
Striving to improve one's health is associated with numerous data alleging that consumption of large amounts of red meat and products made thereof is fraught with cancer diseases. The price of food products matters for a part of consumers, but this data may be not relevant for the majority of countries because the price for alternative plant-based food products in Ukraine is much higher than the price for conventional animal-based food products. At the same time, the safety of foods and distrust of the labeling of animal-based food products are subjects of concern because such products may contain residues of hormones and antibiotics used for animal breeding which are not indicated on the labels or package. A minority of consumers choose a plant-based diet as an alternative to traditional food products. This is especially important for those who have problems with health (such as intolerance of lactose) but do not want to abandon all the conventional food products. Surprisingly, only $2 \%$ of consumers reported a plant-based diet to be a component of a healthy lifestyle. Of the essential reasons driving the respondents to consume plant-based milk analogues, commitment to a healthy lifestyle, health condition (the existence of lactose intolerance), and enjoyment of the product taste should be emphasized (Figure 5). The data in Figure 5 show that the principal reason for the plant-based milk analogues consumption is a commitment to a healthy lifestyle (35.8\% of the respondents). $14.3 \%$ of the consumers suffer from specific metabolism diseases such as lactose intolerance. On the other hand, the allergy affects only $3 \%$ of the consumers, because the milk allergy quite rarely occurs in the adult age.

$12.4 \%$ of the consumers give preference to plant-based milk analogues because they enjoy the product taste. We also found out that only $10 \%$ of the consumers prefer plant-based milk analogues in the daily diet because of environmental concerns and ethical treatment of animals. These results confirm the findings and data on the reasons for the consumption of plant-based food products published previously (Stannard, 2018).

It should be noted that the majority of the reasons are largely explained by the impact of media sources on the marketing strategies of manufacturers. Food products made of plant-based raw materials are undoubtedly useful for health and should be included in a diet although they can harm the human body and the environment. Plantbased food products may contain residues of pesticides and chemical fertilizers; their manufacturing may affect the environment, especially in cases when food products are made from genetically modified soybeans. Therefore, a consumer should not abandon animal-based food products and should switch to a plant-based diet based on the doctor's recommendations. It is also important to take into account that many consumers consider the nutritional value of plant-based milk analogues to be the same as cow's milk, or even more nutritious (Food Insight, 2018; National Dairy Council, 2018). The content of chemicals in milk and its plant-based analogues is significantly different in particular vitamins content and protein digestibility (Mäkinen et al., 2016; Jeske, Zannini and Arendt, 2017; Carvalho et al., 2001; Haas et al., 2019). Based on the mentioned facts, we can identify special categories of consumers of alternative food products as follow: solvent consumer segment that wants to taste unusual foods, fans of a healthy diet and environmental activists - protectors of animals and fighters for the clean environment. In Ukraine young people (younger than 30 years old) experiment with diets and consume plant-based milk analogues more often than in the world where plant-based analogues of milk are mostly consumed by women aged $30-34$ and $55-64$, and men aged $55-64$ and elder than 64 (Crosser et al., 2019).

As we have already mentioned, plant-based analogues of food products are preferred by the well-off population with a rather high-income level. Results show that there are $12.9 \%$ of consumers of plant-based analogues of milk and $12.0 \%$ of consumers of plant-based analogues of meat with annual income 50 - 59,999 USD and 60 - 69,999 USD; $35.0 \%$ of consumers of plant-based analogues of milk and $37 \%$ of consumers of plant-based analogues of meat with the income of 100,000 USD or more (Crosser et al., 2019). Regarding Ukraine, the majority of respondents consider prices for plant-based milk analogues as too high (Figure 6).

Data in Figure 6 confirm that prices for plant-based milk analogues are too high for $63.1 \%$ of consumers of these products, and for $63.1 \%$ of the consumers that do not consume plant-based milk analogues. It is statistically tested that there is no significant difference between the assessment of price for plant-based milk analogues by the consumers who consume plant-based milk and consumers who do not consume them $(p=0.004$, i.e. $p<0.05)$. A review of literature sources confirms that the majority of consumers around the world, which stick with the principles of a healthy diet, prefer plant-based substitutes of milk (Schmidt, 2018; Mascaraque, 2020).

According to the questioning of consumers who live healthily and prefer natural and organic food products, the majority of them prefer plant-based analogues of milk. This results in consumers with a healthy lifestyle. For the majority of respondents, the consumption of plant-based milk analogues is associated with a healthy lifestyle ( $48.5 \%$ of the ones consuming this product, and $47.7 \%$ of the ones not consuming it) (Figure 7).

Regarding the taste preferences, the largest share of consumers $(20.4 \%)$ prefer almond milk, and $15.3 \%$ of consumers oat milk. $16.2 \%$ of the respondents have no preference regarding plant-based milk (Figure 8).

Results in Figure 9 show, that the most favorite plantbased milk analogues trademarks are (Alpro) $(25.0 \%)$ and (EcoMil) (14.3\%). Only 3.1\% of the respondents have no trademark preferences.

The consumer choice of plant-based milk analogues is influenced by many factors such as price, quality, taste characteristics, product composition, and producer (Figure 10) (McCarthy et al., 2017). The most important factor of purchasing decisions is taste characteristics (reported by $38.1 \%$ of the ones consuming this product, and $38.5 \%$ of the ones not consuming it), followed by price (reported by $21.2 \%$ and $20.0 \%$ ). It is demonstrated that no significant variations occur in the criteria of choice of plant-based milk analogues ( $p=0.000$, i.e. $p<0.05$ ). 


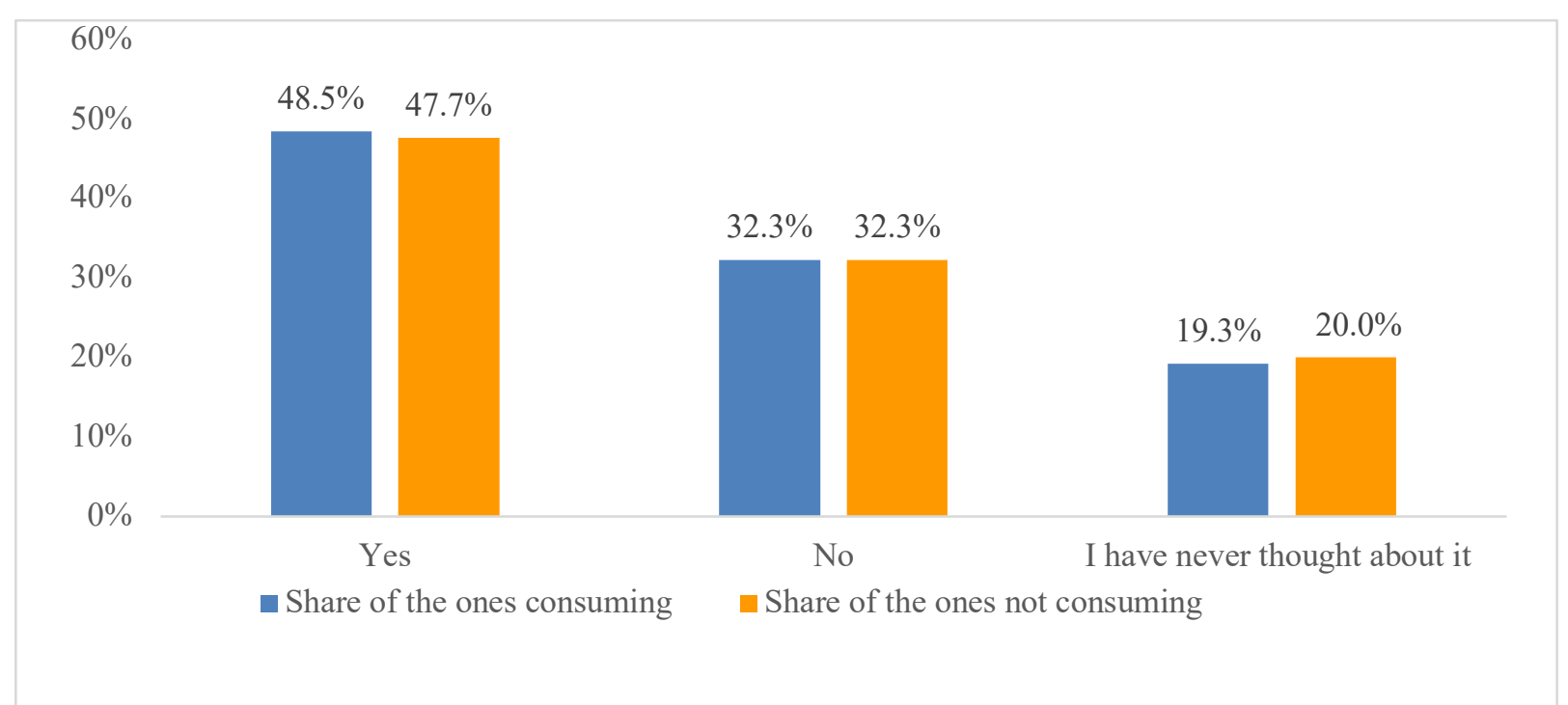

Figure 7 An analysis of associating consumption of plant-based milk analogues with the healthy lifestyle.

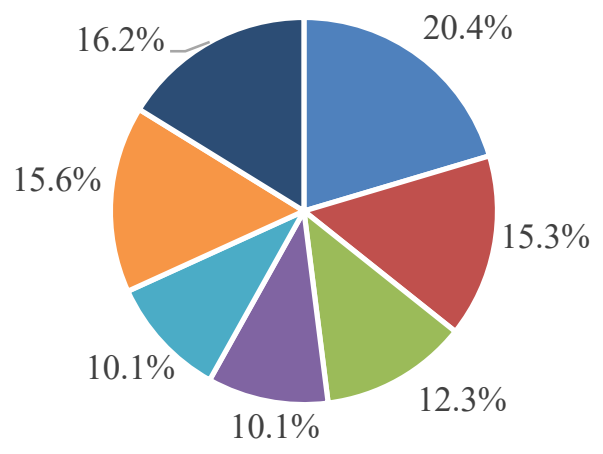

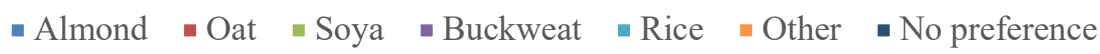

Figure 8 Preferences of plant-based milk analogues.

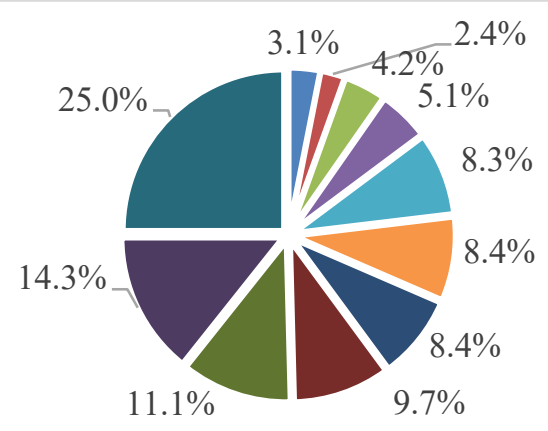

$$
\begin{array}{ll}
\text { - No trade mark preferences } & \text { - Other } \\
\text { - OraSi } & \text { - Mand'or } \\
\text { - Soja } & \text { - Joya } \\
\text { - EcoMil } & \text { - Alpro }
\end{array}
$$

- KARA

- Vega Milk

- Ideal Nemoloko

Figure 9 Trademark preferences of plant-based milk analogues. 


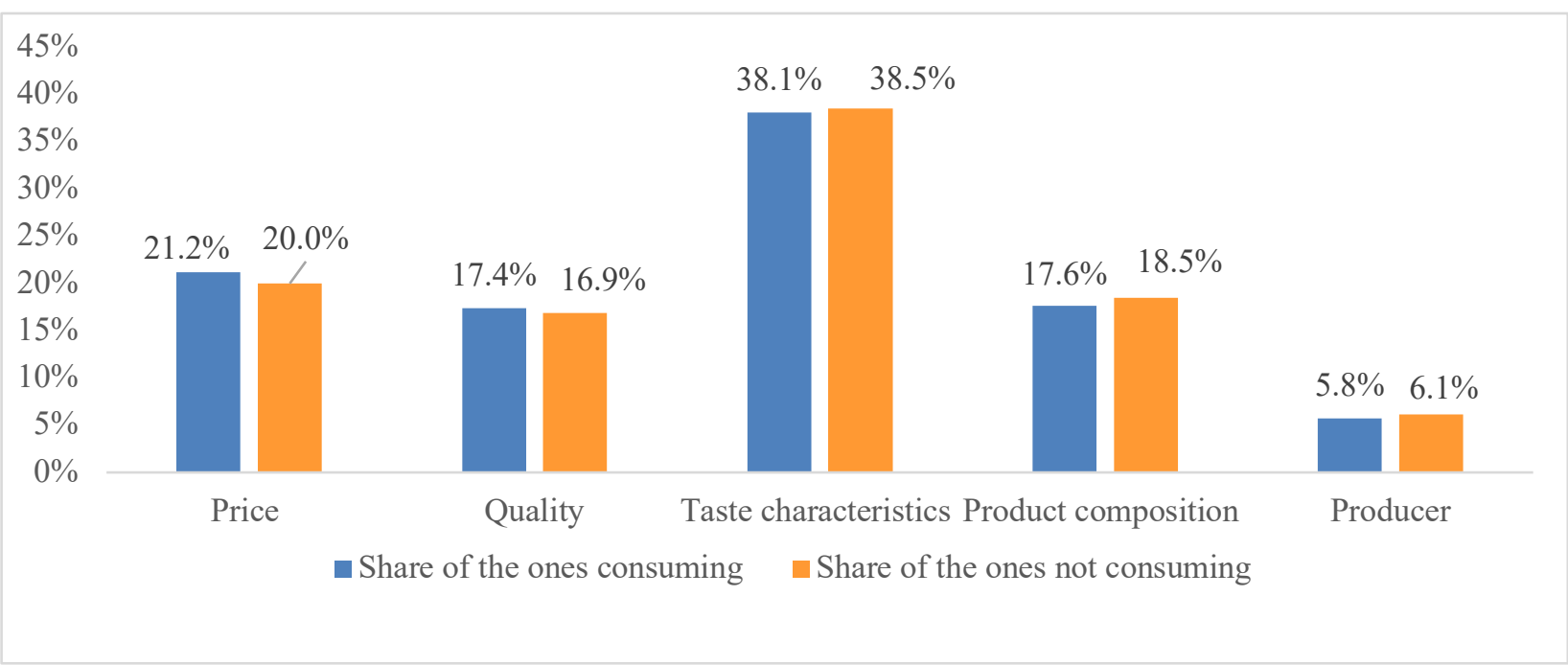

Figure 10 Criteria of choice of plant-based milk analogues.

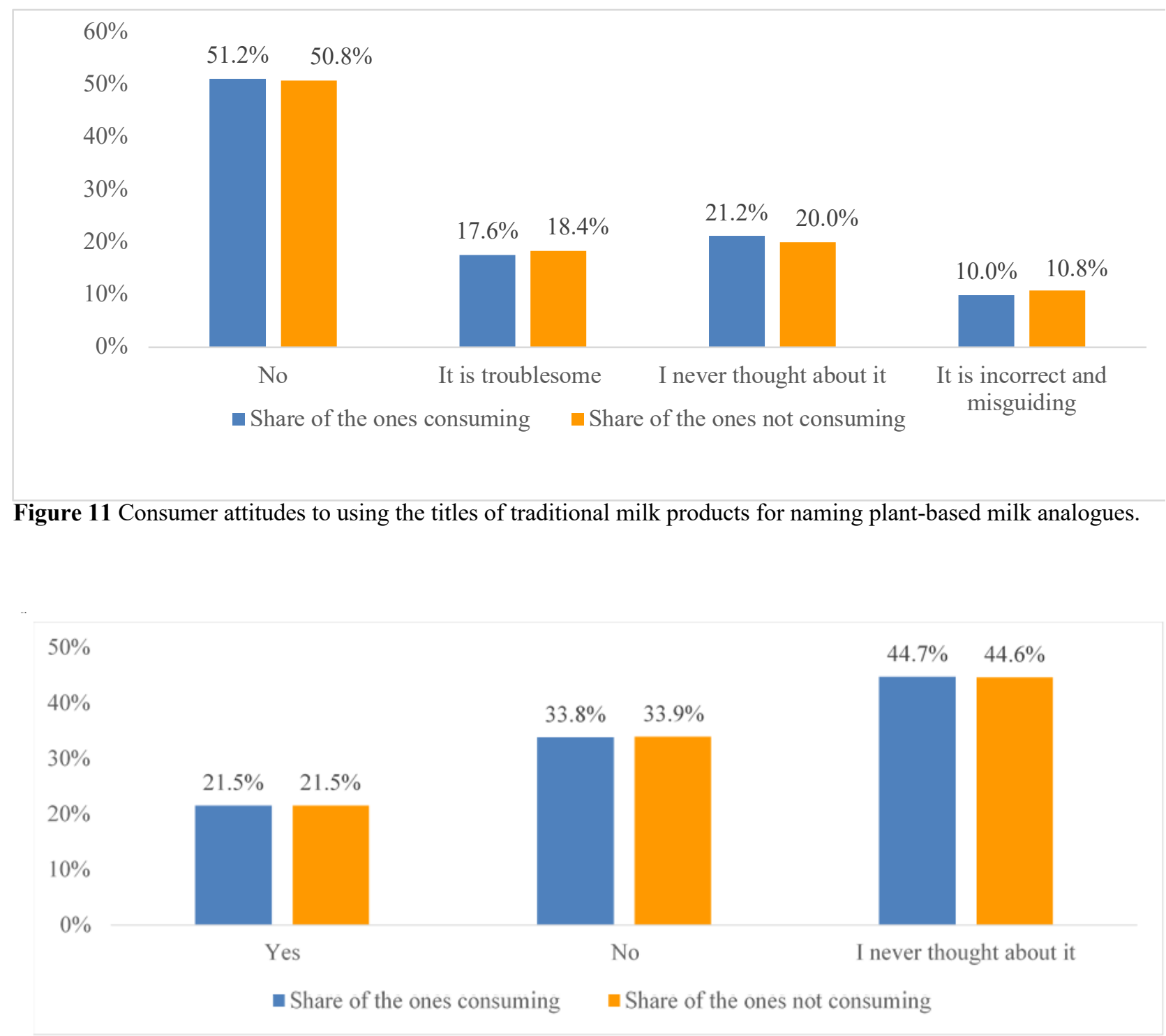

Figure 12 Consumers' awareness of the differences between traditional milk and its plant-based analogues in terms of understanding the differences between traditional products and their plant-based analogues. 
We consider the term plant-based analogue of milk to be more correct than the others because an analogue means something with similarities or likenesses to another object or phenomenon. These food products tend to be called "milk" due to their similarity in appearance and contents with animal milk. Another important factor is that such extracts are a favorable environment for microflora, thus enabling their use for making yogurts, ice cream, cheese, etc.

Plant-based milk analogue is a drink made by milling a vegetable raw material and mixing it with water, further homogenization of a liquid resulting in the distribution of particles by size within the limit of $20 \mu \mathrm{m}$. The final product imitates cow milk by appearance and contents. However, the majority of consumers agree that the name of traditional milk products can be easily used to label their plant-based analogues (Figure 11).

The research results confirm that $51.2 \%$ of consumers accept that the name of traditional milk products (such as "milk") is used for plant-based milk analogues labeling. At the same time, only almost $10 \%$ of the respondents think that it would be incorrect and misleading. It is demonstrated that no significant variation occurs in the response to the question "Do you consider using the name of traditional milk products ("milk") for labeling of plantbased milk analogues to be a problem?" ( $p=0.001$, i.e. $p<0.05$ ).

The results also reveal that consumers, who are not sufficiently informed about the origin of plant-based milk analogues, do not understand the differences between traditional products and their plant-based analogues (Figure 12).

The majority $44.7 \%$ of respondents have never thought about whether plant-based milk analogues have similar nutritional or biological value as milk. However, one of the three respondents thinks that plant-based drinks are not similar to cow milk by nutritional or biological value. It is statistically tested that no significant variation occurs in the responses to this question given by the ones consuming and not consuming plant-based milk $(p=0.005$, i.e. $p<0.05$ ).

Since almost one-half of our respondents have never thought about the identity of plant-based milk analogues and traditional milk by nutritional or biological value, it indicates their inadequate awareness. At the same time, it may harm public health because the chemical composition, nutritional and biological value of the traditional milk and its plant-based analogues are essentially different; in particular, by composition and biological accessibility of protein and calcium, which deficit may cause certain health problems.

\section{CONCLUSION}

The market of plant-based milk analogues has been rapidly expanding. There is an upward tendency in the consumer demand for plant-based milk analogues, although this food segment has not yet been popular for consumers. This opens up opportunities for further development and new product launching at the market. The research results (covering 436 respondents) show that the sample, being diverse enough, could demonstrate consumer treatment of this product group, market supply, prices, and tendencies.
Using z-criterion, the following findings could be made and confirmed statistically:

1. Plant-based milk analogues have certain differences in the majority of real and potential consumers compared with traditional milk. They are for the most part associated with the healthy lifestyle, ethical treatment of animals, environmental concerns, and problems with one's health (which proves hypothesis 1 ).

2. Research results do not demonstrate a strong differences between the consumers that consume plantbased milk analogues and the ones that do not consume them (the significance of $\mathrm{z}$-criterion is much less than 0.05 ). Therefore we can conclude that appropriately chosen promotional tools can affect potential consumers of plant-based milk analogues and thus increase the demand (which proves the hypothesis 2).

3. Respondents mostly make a choice of plant-based milk analogues based on the product taste. It implies that producers should expand the assortment line of their products by experimenting with various tastes to attract potential consumers. Especially since the main consumers of plant-based milk analogues are people younger than 30 years old, i.e. the consumers seek for innovations and experiments in the diet (which proves hypothesis 3 ).

4. Producers of plant-based milk analogues should carefully take the production costs and producer prices into consideration. As the research results show, price reduction increases the sales of this product (which proves hypothesis 4).

\section{Acknowledgments:}

The authors thank Ms Małgorzata Wecko (Wrocław University of Economics) for help in preparing bibliometric data.

\section{REFERENCES}

Agroreview. 2018. When a Cow Is Not Needed: How to Make Money on Plant-Based Milk Production (Коли не потрібна корова: як заробити на виробництві рослинного молока). (In Ukrainian) Available at: https://agroreview.com/news/koly-ne-potribna-korova-yakzarobyty-na-vyrobnyctvi-roslynnoho-moloka

Bestfoodfacts. 2017. Plant-Based Milk vs. Cow's Milk: What's the Difference? Available at: https://www.bestfoodfacts.org/is-plant-based-milk-healthy/

Biswas, S., Sircar, D., Mitra, A., De B. 2011. Phenolic constituents and antioxidant properties of some varieties of Indian rice. Nutrition and Food Sciences, vol. 41, no. 2, p. 123-135. https://doi.org/10.1108/00346651111117391

Burke, N., Zacharski, K. A., Southern, M., Hogan, P., Ryan, M. P., Adley, C. C. 2018. The Dairy Industry: Process, Monitoring, Standards, and Quality. In Valero Diáz, A., Garciá-Gimeno, R. M. Descriptive Food Science. ISBN 9781-83881-725-1. https://doi.org/10.5772/intechopen.80398

Burton, G. W., Ingold, K. U. 1989. Vitamin E as an in Vitro and in Vivo antioxidant. Annals of the New York Academy of Sciences, vol. 570, no. 1, p. 7-22. https://doi.org/10.1111/j.1749-6632.1989.tb14904.x

Carvalho, N. F., Kenney, R. D., Carrington, P. H., Hall, D. E. 2001. Severe Nutritional Deficiencies in Toddlers Resulting From Health Food Milk Alternatives. Pediatrics, vol. $107, \quad$ no. $4, \quad$ e46, 7 p. https://doi.org/10.1542/peds.107.4.e46 
Crosser, N., Bushnell, C., Derbes, E., Friedrich, B., Gaan, K., Ignaszewski, E., Lamy, J., Manu, N., Weston, Z. 2019. Plant-based Meat, Eggs, and Dairy. State of the Industry Report. Available at: https://www.gfi.org/files/soti/INNPBMED-SOTIR-2020-0507.pdf

Doris, C. 2018. Mimicking Meat, Seafood, and Dairy. Food technology magazine, vol. 72 , no. 5. Available at: https:/www.ift.org/news-and-publications/food-technologymagazine/issues/2018/may/features/meat-free-alternatives

FAO. 2016. About the International Year of Pulses. Available at: http://www.fao.org/pulses-2016/about/en/

Fedulova, I. 2018. Ukraine's dairy market: opportunities and threats (Ринок молочної продукції України: можливості та загрози). Commodities and markets, no. 1, p. 15-28. (In Ukrainian)

Food Insight. 2018. What's In A Name? Survey Explores Consumers' Comprehension of Milk and Non-Dairy Alternatives. Available at: https://foodinsight.org/whats-in-aname-survey-explores-consumers-comprehension-of-milkand-non-dairy-alternatives/

Future Market Insights. 2019. Dairy Alternatives Market: Veganism Will Remain a Significant Impact Factor Fueling the Demand for Non-dairy Products: Global Industry Analysis Opportunity Assessment (2019-2029). Available at: https:/www.futuremarketinsights.com/reports/dairyalternatives-market

Haas, R., Schnepps, A., Pichler, A., Meixner, O. 2019. Cow Milk versus Plant-Based Milk Substitutes: A Comparison of Product Image and Motivational Structure of Consumption. Sustainability, vol. 11, no. 18, 25 p. https://doi.org/10.3390/su11185046

Haghighat, F., Thimmarayappa, R., Niavand, H. 2015. The Analysis of Marketing Milk Factories and Effects on Customers Behaviours Mechanism. Journal of Accounting \& Marketing, vol. 4, no. 3, 4 p. https://doi.org/10.4172/2168$\underline{9601.1000143}$

Havaza, Y. V. 2015. World Market of Milk and Dairy Products: Trends and Prospects for Ukraine (Світовий ринок молока і молокопродуктів: тенденції та перспективи для України). Economy $A I C$, vol. 7, p. 106-113. (In Ukrainian) Available

Ilchuk, M. M., Radko, V. I. 2013. Adaptation of milk producers in Ukraine to European requirements (Адаптація виробників молока в Україні до європейських вимог). Bioresources and Environmental Management, vol. 5, no. 6, p. 129-137. (in Ukrainian)

Innova Market Insights. 2017. Global Plant Milk Market to Top US \$16 Billion in 2018: Dairy Alternative Drinks Are Booming, Says Innova Market Insights. Available at: https://www.prnewswire.com/news-releases/global-plantmilk-market-to-top-us-16-billion-in-2018--dairy-alternativedrinks-are-booming-says-innova-market-insights-

300472693.html

Jeske, S., Zannini, E., Arendt, E. K. 2017. Evaluation of Physicochemical and Glycaemic Properties of Commercial Plant-Based Milk Substitutes. Plant Foods for Human Nutrition, vol. 72, p. 26-33. https://doi.org/10.1007/s11130016-0583-0

Karpii, O. P., Khtei, N. I., Shul, M. B. 2013. Characteristics of the dairy market in Ukraine (Характеристика ринку молочної продукиії України). Lviv Polytechnic National University Institutional Repository. (In Ukrainian) Available at:

http://ena.lp.edu.ua:8080/bitstream/ntb/28952/1/060_101_102 .pdf
Koshelnyk, A. V., Motuzka, J. M., Babiy, O. V. 2020. Terminological discrepancy in the field of production and circulation of plant-based milk analogues (Термінологічна неузгодженість у сфері виробництва та обігу аналогів молока рослинного походження). Herald of Lviv University of Trade and Economics. Technical Sciences, no. 23, p. 157165. (In Ukrainian) https://doi.org/10.36477/2522-1221-202023-21

Krivošíková, A., Nagyová, L., Kubelaková, A., Mokrý, S. 2019. Consumer Preferences on Milk Market: Evidence from Slovak Republic. Potravinarstvo Slovak Journal of Food Sciences, vol. 13, no. 1, p. 961-970. https://doi.org/10.5219/1221

Kubicová, L', Habánová, M. 2012. Development of Milk Consumption and Marketing Analysis of its Demand. Potravinarstvo Slovak Journal of Food Sciences, vol. 6, no. 4, p. 66-72. https://doi.org/10.5219/236

Lagally, C., Clayton, E. R., Specht, L. 2017. Plant-Based Meat Mind Maps: An Exploration of Options, Ideas, and Industry. Available at: https://www.gfi.org/files/PBMap.pdf

Mäkinen, O. E., Wanhalinna, V., Zannini, E., Arendt, E. K. 2016. Foods for Special Dietary Needs: Non-Dairy PlantBased Milk Substitutes and Fermented Dairy-Type Products. Critical Reviews in Food Science and Nutrition, vol. 56, no. 3, p. 339-349. https://doi.org/10.1080/10408398.2012.761950

Mandalari, G., Nueno-Palop, C., Bisignano, G., Wickham, M. S. J., Narbad, A. 2008. Potential Prebiotic Properties of Almond (Amygdalus Communis L.) Seeds. Applied and Environmental Microbiology, vol. 74, no. 14, p. 4264-4270. https://doi.org/10.1128/AEM.00739-08

Mascaraque, M. 2020 The unstoppable rise of plant-based alternatives. Available at: https://blog.euromonitor.com/theunstoppable-rise-of-plant-based-alternatives/

McCarthy, K. S., Parker, M., Ameerally, A., Drake, S. L., Drake, M. A. 2017. Drivers of choice for fluid milk versus plant-based alternatives: What are consumer perceptions of fluid milk? Journal of dairy science, vol. 100, no. 8, p. 61256138. https://doi.org/10.3168/jds.2016-12519

National Dairy Council. 2018. The Importance of Milk's 9 Essential Nutrients. Available at: https://www.nationaldairycouncil.org/sitecore/content/dg/hom e/content/2018/the-importance-of-milks-9-essential-nutrients

Omoni, A. O., Aluko, R. E. 2005. Soybean Foods and Their Benefits: Potential Mechanisms of Action. Nutrition Reviews, vol. 63, no. 8, p. 272-283. https://doi.org/10.1111/j.17534887.2005.tb00141.x

Popescu, A. 2015. Research on the Trends in Milk Production and Consumption in Romania. Scientific Papers Series Management, Economic Engineering in Agriculture and Rural Development, vol. 15, no. 1, p. 387-392. Available at:

http://managementjournal.usamv.ro/pdf/vol.XV 1/Art58.pdf

Proconsulting. 2019. Business plan for $\bar{a}$ plant milk production project (Бізнес-план проекту виробництва рослинного молока). (in Ukrainian) Available at: https://proconsulting.ua/ua/biznes-plan/biznes-plan-proekta-

proizvodstva-rastitelnogo-moloka

Schmidt, S. 2018. Infographic on Milk \& Dairy Alternatives: Consumer Trends. Available at: https://blog.marketresearch.com/infographic-milk-and-dairyalternatives-consumer-trends

Sethi, S., Tyagi, S. K., Anurag, R. K. 2016. Plant-Based Milk Alternatives an Emerging Segment of Functional Beverages: A Review. Journal of Food Science and Technology, vol. 53, p. 3408-3423. https://doi.org/10.1007/s13197-016-2328-3 
Stannard, S. 2018. Consumer Insights. Available at: https://media.ahdb.org.uk/media/Default/Consumer\%20and\% 20Retail\%20Insight\%20Images/PDF\%20articles/ConsumerIn sights\%20WEB_1653_180725.pdf

The Vegan Society. 2018. Statistics - The Vegan Society. Available

https://www.vegansociety.com/news/media/statistics

Tycha, I. V., Stetsenko, O. D. 2017. Condition and Tendency of National Milk and Dairy Products Market (Стан та тенденції розвитку вітчизняного ринку молока та молочних продуктів). Effective economy, vol. 3. (In Ukrainian) Available

http://www.m.nayka.com.ua/?op=1\&j=efektyvnaekonomika\&s $=$ ua\&z $=5427$

Vanga, S. K., Raghavan, V. 2018. How Well Do Plant Based Alternatives Fare Nutritionally Compared to Cow's Milk? Journal of Food Science and Technology, vol. 55, p. 10-20. https://doi.org/10.1007/s13197-017-2915-y

Vlasenko, I. H. 2013. The State of the World Market of Milk and Dairy Products and the Features of Its Formation in Ukraine (Стан світового ринку молока i молочної продукції та особливості його формування в Україні). Innovative economy, no. 1, p. 38-41. (In Ukrainian) Available at: http://nbuv.gov.ua/UJRN/inek_2013_1_12

Wild, F., Czerny, M., Janssen, A., Kole, A., Žunabović, M., Domig, K. J. 2014. The Evolution of a Plant-Based Alternative to Meat. From niche markets to widely accepted meat alternatives. Agro Food Industry Hi-tech, vol. 25, no. 1, p. 45-49. Available at: https://pdfs.semanticscholar.org/cf90/d287aa226b483aed430f f4f0432081bfd3d7.pdf

Yashchenko, L. O. 2016. Statistical Forecasting of Producer Price Index for Foods, Beverages and Tobaccos (Статистичне прогнозування індексу цін виробників харчових продуктів, напоїв та тютюнових виробів). Statistics of Ukraine, vol. 3, p. 25-32. (In Ukrainian) Available at: https://sujournal.com.ua/index.php/journal/article/view/105/94

Zegler, J. 2017. 2017 Global food \& drink trends: how did we do? Available at: https://www.mintel.com/blog/foodmarket-news/2017-global-food-drink-trends-how-did-we-do12

Zik. 2017. B There Are Two Million Vegetarians in Ukraine - Poll (Україні два мільйони вегетаріанців, опитування). (In Ukrainian) Available at: https://zik.ua/news/2017/10/23/v_ukraini_dva_milyony_veget ariantsiv_opytuvannya_1191465

\section{Contact address:}

Natalia Prytulska, Kyiv National Trade and Economic University, Department of Commodity Science, safety and quality management, st. Kyoto, 19, Kyiv, Ukraine, 02156, Tel.: +38067-691-84-77,

E-mail: pritulska@knteu.kiev.ua

ORCID: https://orcid.org/0000-0002-9010-4190

*Iuliia Motuzka, Kyiv National Trade and Economic University, Department of Commodity Science, safety and quality management, st. Kyoto, 19, Kyiv, Ukraine, 02156 , Tel.: +38067-719-03-74,
E-mail: unmot@ukr.net

ORCID: https://orcid.org/0000-0003-0400-6445

Anna Koshelnyk, Kyiv National Trade and Economic University, Department of Commodity Science, safety and quality management, st. Kyoto, 19, Kyiv, Ukraine, 02156, Tel.: +38096-431-54-33,

E-mail: a koshelnyk@ukr.net

ORCID: https://orcid.org/0000-0002-0322-9375

Olena Motuzka, National Academy of Statistics, Accounting and Audit, Department of Economics and Management of Foreign Economic Affairs, Pidhirna str. 1, Kyiv, Ukraine, 04107, Tel.: +38067-255-62-74,

E-mail: olmotuzka@gmail.com

ORCID: https://orcid.org/0000-0001-9028-6994

Ludmila Yashchenko, Food Resources Institute of the National Academy of Agrarian Sciences of Ukraine, Department of Economic Research and innovation provision, E. Sverstiuk str., Kyiv, Ukraine, 02002, Tel.: +380965787841,

E-mail: lud ya@ukr.net

ORCID: https://orcid.org/0000-0002-4893-8191

Malgorzata Jarossová, University of Economics in Bratislava, Faculty of Commerce, Department of Commodity Science and Product Quality, Dolnozemská cesta č. 1, 85235 Bratislava 5, Slovakia, Tel.: +421944647327,

E-mail: malgorzata.jarossova@euba.sk

ORCID: https://orcid.org/0000-0003-2006-8339

Paulína Krnáčová, University of Economics in Bratislava, Faculty of Commerce, Department of Commodity Science and Product Quality, Dolnozemská cesta č. 1, 85235 Bratislava 5, Slovakia, Tel.: +421267291126,

E-mail: paulina.krnacova@euba.sk

ORCID: https://orcid.org/0000-0002-5371-1661

Joanna Wyka, Wroclaw University of Environmental and Life Sciences, Departmen of Human Nutrition, Chełmońskiego 37, 51-630 Wrocław, Poland, Tel.: +48 71 3207757 ,

E-mail: joanna.wyka@upwr.edu.pl

ORCID: https://orcid.org/0000-0003-3894-8318

Ewa Malczyk, University of Applied Sciences in Nysa, Department of Health Sciences, Armii Krajowej7, 48-300 Nysa, Poland, Tel.: +48609145308,

E-mail: ewa.malczyk@pwsz.nysa.pl

ORCID: https://orcid.org/0000-0001-5111-2748

Marta Habánová, Slovak University of Agriculture, Faculty of Agrobiology and Food Resources, Department of Human Nutrition, Trieda A. Hlinku2, 94976 Nitra, Slovakia, Tel.: +421904665196,

E-mail: marta.habanova@uniag.sk

ORCID: https://orcid.org/0000-0003-1721-7161

Corresponding author: * 